\title{
Joggyakorlat
}

\author{
BaLLA LAJOS*
}

\section{Az emberölés értékelése - jogszabályi keretek és a Debreceni Ítélőtábla gyakorlata}

\author{
Emberölés - büntetéskiszabási elvek - enyhítő és súlyositó körülmények - \\ ügyvizsgálat - Debreceni Ítélőtábla
}

A büntetőjog fogalomrendszerében a bủncselekmény és az ehhez szorosan hozzá tartozó elkövető mellett a harmadik meghatározó kategória a büntetés. A fogalommal kapcsolatos változásokat jól érzékelteti Földvári József, amikor megállapítja: „a büncselekmény tanának évszázada a XIX. század volt, míg a büntetés tanáé a XX., illetve talán a XXI. század."

Egyes szerzők szerint a jelenlegi büntetőjogi gondolkodást vizsgálva ma már nem beszélhetünk csupán a „büntetésröl” mint önálló kategóriáról, sőt a joghátrány, a szankció jellemzői is átértékelődnek, mind szorosabban összekapcsolódnak a korábban tisztán anyagi jogi, eljárási, illetve végrehajtási normák. Előtérbe kerülnek a közvetlenül érzékelhető hátrányt csak áttételesen jelentő jogintézmények, mint például a büntetés elhalasztásában, felfüggesztésében megjelenő következmények. Ezeken túl új technikák, eszközök törik meg a korábbi zárt rendszert, nem kis fejtörést okozva a jogalkalmazónak. A jogkövetkezmények között szerepelnek immár a bűncselekmények áldozatainak, sértettjeinek kártalanítását, a bűncselekmény hatásait enyhítő jogintézmények is. A „helyreállító” igazságszolgáltatás keretében pedig a büntető útról elterelő szabályok térnyerése észlelhető.

Felvetődik tehát a kérdés: van-e egyáltalán létjogosultsága a "hagyományos” büntetésközpontú gondolkodásnak, vagy ha nincs, a gyakorlatnak egészen más irányba

* Dr. Balla Lajos elnökhelyettes, Debreceni Ítélötábla; c. egyetemi docens, DE ÁJK Büntetőjogi és Kriminológiai Tanszék. ballal@dit.birosag.hu. 
kell-e fordulnia a büntetőjogi szankció alkalmazása során. Hasonló változás érzékelhető a büntetés jogalapjára ${ }^{1}$ és céljára ${ }^{2}$ vonatkozó nézeteket illetően is.

A tanulmány témája az emberölés miatt indult büntetőügyekben tapasztalható büntetéskiszabási gyakorlat alakulása. Mielött azonban az ügyvizsgálattal alátámasztott kérdésekre irányítanám a figyelmet, szeretném röviden áttekinteni a hazai szabályozástörténet föbb csomópontjait.

\section{1. Értékelés a jogalkotásban}

\subsection{A dualizmus kori szabályozás}

Az 1878. évi V. törvénycikk, azaz a Csemegi-kódex III. fejezetében található a szankciórendszer leírása, a szabadságelvonással járó büntetéseket a végrehajtási fokozatok jellege szerint megkülönböztetve.

A IV. fejezet 89. §-a rendelkezett arról, hogy „a büntetések kiszabásánál figyelembe veendők a bünösség fokára befolyással bíró súlyosító és enyhítő körülmények". Bár a törvényi rendelkezések az enyhítő és súlyosító körülmények tételes felsorolásától tartózkodtak, e körülmények fennállásának a $90 .^{3}$, illetve a $91 . \S^{4}$ kitüntetett jelentőséget tulajdonítanak, a 92 . $\S^{5}$ pedig az adott büntetési nem legkisebb mértékének az enyhébb büntetési nem irányába történő átlépésére adott lehetőséget.

Hasonló elvek alapján tartalmazta a később hatályba lépő 1908. évi XXXVI. törvénycikk a fiatalkorúakra vonatkozó szankciórendszer elemeit, illetőleg az enyhítő és súlyosító körülmények figyelembevételének lehetőségét is, a vétőképesség korhatárát a 12. életév betöltésében határozva meg. ${ }^{6}$

A később vázoltakra is tekintettel szükséges megjegyezni, hogy a Csemegi-kódex 279. §-a a szándékos emberölés bűntette vonatkozásában 10 évtől 15 évig terjedő fegyházbüntetést helyezett kilátásba.

1 A büntetés jogalapja voltaképpen azt jelenti, milyen felhatalmazás, jogcím alapján kerülhet sor a büncselekményt elkövető személy megbüntetésére, ki és milyen alapon rendelkezik legitimációval büntetőjogi joghátrány alkalmazásával. - BÉkÉs Imre (szerk.): Büntetőjog. Általános Rész, Budapest, HVG-ORAC, 2003, 233.

2 Két fő vonulat figyelhető meg: a bủncselekmény elkövetésére reagáló (abszolút) elmélet és a jövőbeni bűncselekmény megakadályozását célzó (relatív) nézetrendszer. Vö.: Uo., 234.

3 „Ha a súlyosító körülmények - számuk vagy nyomatékuk - tekintetében túlnyomók: a büntetésnek az elkövetett cselekményre megállapított legmagasabb mértéke megközelítendő vagy alkalmazandó."

4 „Ha pedig az enyhítő körülmények túlnyomóak a cselekményre megállapított büntetésnek legkisebb mértéke megközelítendő vagy alkalmazandó."

5 „Ha pedig az enyhítö körülmények annyira nyomatékosak, vagy olyan nagy számmal forognak fenn, hogy a cselekményekre meghatározott büntetésnek legkisebb mértékben is aránytalanul súlyos lenne: ez esetben ugyanazon büntetési nem a legkisebb mértékig leszállitható, és ha ez is túl szigorú volna: határozott időtartamhoz kötött fegyház helyett börtön, - börtön helyett fegyház, - fogház helyett pénzbüntetés, - ezen büntetési nemek legkisebb mértékig állapitható meg. Halálbüntetés helyett tizenöt évi, - életfogytig tartó fegyház helyett pedig tízévi fegyháznál kisebb büntetés a jelen § esetében nem állapítható meg."

6 1908. évi XXXVI. törvénycikk 15. §: „Az ellen aki a büntett vagy vétség elkövetésekor életének 12. évét meg nem haladta (gyermek) sem vád nem emelhetö, sem bünvádi eljárás nem inditható." 


\subsection{Az 1950. évi II. törvény}

A Büntető Törvénykönyv Általános Részéröl szóló 1950. évi II. törvény (Btá., amely az 1950. évi 39. tvr. alapján 1951. január 1. napján lépett hatályba) 30. §-a a büntetési nemeket rögzíti. A Csemegi-kódexhez hasonlóan a szankciórendszer leírása mellett a fenti jogszabály is tartalmaz instrukciókat a jogalkalmazók számára a büntetés kiszabását illetően, bár azok nem mentesek a politikai direktíváktól. ${ }^{7}$

Megjegyzendő, hogy a büntetés kiszabásával kapcsolatos szempontokat e jogszabály a Csemegi-kódex szerinti logikai sorrendben és a Csemegi-kódex szerinti okfejtéssel tartalmazza. Rendelkezik a jelenlegi fogalmaink szerint az ún. enyhítő szakasz alkalmazásának a lehetőségéröl, megállapítja például, hogy ha a törvényben megállapított büntetés halál, ehelyett életfogytig tartó vagy 15 évig terjedhető börtönbüntetés szabható ki, rendelkezik továbbá arról is, hogy a büntetést a törvény által meghatározott kereten belül olyan mértékben kell kiszabni, hogy az igazodjék többek között az elkövető terhére, illetőleg javára egyébként figyelembe jövő körülményekhez és az okozott sérelmekhez is. Zárójelbe teszi az 50. § (2) bekezdés: „a büntetést súlyositó és enyhitő körülmények az elöbbiek".

A szabadságelvonó büntetés mellett ismerte tehát az életfogytiglani és a határozott ideig tartó szabadságvesztést, s megfigyelhető a kor anyagi jogi jogszabályaiban, hogy a halálbüntetés alkalmazására a Csemegi-kódexhez képest kiterjedtebben kerülhet sor. ${ }^{8}$

A témánk szempontjából jelentős tényállások az összeállítás 5 . részében találhatók, amely a polgárok személye és javai ellen irányuló búncselekményeket taglalja. Az elöre megfontolt szándékból elkövetett emberölés leírását a 349. pont tartalmazza, ${ }^{9}$ a 351 . pont pedig a szándékos emberölés tényállását határozza meg. ${ }^{10}$ Megjegyzendő, hogy a tényállások teljesen azonosak a Csemegi-kódex megfelelő tényállásaival, erre utal a korabeli jogszabály azzal, hogy felhívja a Csemegi-kódex 278., illetőleg 279. §-át. Mivel az 1952-ben összeállított joganyag az élettel és testi épséggel kapcsolatos tényállások körében szinte teljesen átvette a Csemegi-kódex szabályozását, nem túlzás annak rögzítése, hogy az élet elleni büncselekmények vonatkozásában a Csemegi-kódex szabályai léteztek egészen az 1961. évi V. törvény hatálybalépéséig.

7 1950. évi II. törvény 50. § (1) bekezdés: „A büntetést a dolgozó nép védelmében az elkövető megjavitása, nevelése, továbbá általában a társadalom tagjainak a bünözéstől való visszatartása végett kell alkalmazni."

8 Hatályos anyagi büntetőjogi szabályok hivatalos összeállitása, Budapest, Jogi és Államigazgatási Könyv- és Folyóirat Kiadó, 1952, 70.

9 „Aki embert elöre megfontolt szándékból megöl, a gyilkosság büntettét követi el és halállal büntetendő.”

10 „Aki embert szándékosan megöl, ha szándékát nem elöre fontolta meg: a szándékos emberölés büntettét követi el és 10 évtöl 15 évig terjedhetö börtönnel büntetethetö." 


\subsection{Az 1961. évi V. törvény}

Az 1961. évi V. törvény, az új Büntető Törvénykönyv megalkotásának egyik célja nyilvánvalóan a Btá., illetőleg az Általános Rész mellett lévő különös részi szabályok - melyek jó része a Csemegi-kódextől hatályos volt - egységes keretbe foglalása. Az 1961. évi V. törvény mintegy tíz évig volt hatályban anélkül, hogy lényeges módosításon átesett volna. ${ }^{11}$

A Btk. megvalósította a jogkövetkezmények egységes elveken nyugvó szabályozását, és ezzel együtt megteremtette az Általános és Különös Rész összhangját. ${ }^{12} \mathrm{~A}$ kódex feltétlen elörelépése a halálbüntetés kivételes jellegének nemcsak hangsúlyozása, hanem az is, hogy a korábbi jogszabályokhoz képest valóban korlátozta a halálbüntetés alkalmazásának lehetőségét, illetve nagyobb hangsúlyt adott a büntetés nevelő jellegének. Az 1971. évi novella a halálbüntetés további szükítése mellett határozott. Mellőzte például a halálbüntetés alkalmazását a vagyon elleni büncselekmények vonatkozásában, s ismételten bevezette az életfogytig tartó szabadságvesztést azon büntettek vonatkozásában, amelyekre egyébként a jogszabály halálbüntetés alkalmazását is lehetővé tette. Lehetővé tette a feltételes szabadságra bocsátást abban az esetben, ha az életfogytig tartó szabadságvesztésre ítélt a büntetéséböl 15 évet már letöltött.

A jogszabály a 34 . §-ban határozta meg a büntetés célját. ${ }^{13}$ Figyelemre méltó a normaszöveg miniszteri indokolása: „a javaslat a dolgozó nép védelme helyett a társadalom védelméröl beszél, ti. ha a büntett tartalmi eleme a társadalomra veszélyesség, helyesebb a büntetés céljának meghatározásában is a társadalom kifejezés használata." A törvény 35. §-a sorolja fel a fö-, valamint a mellékbüntetéseket. A szankciórendszer alkalmazásával kapcsolatosan a törvény IV. fejezete ad a büntetés kiszabása körében szempontokat. A Btk. 64. §-a az 1950. évi II. törvényhez hasonlóan körvonalazza a büntetés kiszabásának elveit. ${ }^{14} \mathrm{~A}$ jogszabály szükségesnek tartja a büntetéskiszabás elvei körében a halálbüntetés vonatkozásában megjegyezni, hogy azt csak akkor kell kiszabni, ha a büntetés célja más büntetéssel nem érhetö el. ${ }^{15}$

A Btk. Különös Része a XIV. fejezetben tartalmaz szabályokat a személy elleni büntettek vonatkozásában. Az emberölés kapcsán a 253. §-ban - a jelenlegihez hasonlóan - 5-től 15 évig terjedő szabadságvesztéssel fenyegeti a szándékos emberölés alapesetét elkövető személyt. A 253. § (2) bekezdésében felsorolt minősített esetek kapcsán pedig az előbb említett keret alsó határát 10 évre emeli, s 10 évtől 15 évig terjedő szabadságvesztéssel, illetőleg halálbüntetéssel fenyegeti a minősített

Az első lényeges módosító novellája az 1971. évi 28. tvr. volt.

12 GYörgYı Kálmán: Büntetések és Intézkedések, Budapest, Közgazdasági és Jogi Könyvkiadó, 1984, 85-86.

13 „A büntetés célja a társadalom védelme érdekében a büntett miatt a törvényben meghatározott joghátrány alkalmazása, az elkövető megjavítása, továbbá a társadalom tagjainak visszatartása a bünözéstől.”

14 „A büntetést - céljának (34. §) szem előtt tartásával - a törvényben meghatározott keretek között úgy kell kiszabni, hogy igazodjék a büntett és az elkövető társadalomra veszélyességéhez, a bünösség fokához, továbbá az egyéb súlyosító és enyhítő körülményekhez."

15 Btk. 64. § (2) bekezdés. 
emberölést elkövetőt. ${ }^{16} \mathrm{Az}$ emberöléssel kapcsolatos tényállás alap- és minősített esetei körében a szabályozás szakít a Csemegi-kódexben megjelent, majd a BHÖ 349. pontjában leírt, gyilkosság elnevezésủ elkövetési magatartással. Az 1961. évi V. törvényben leírt elkövetési magatartások a korábbiakhoz képest igen cizelláltak, e cizelláltság megközelíti az 1978. évi IV. törvényben rögzített szabályozást. Ebben a körben egyébként a miniszteri indokolás megjegyzi: „a bizonyítási nehézségek folytán a gyilkosság és a szándékos emberölés között teljesen szilárd határvonal máig sem tudott kialakulni. Bizonytalanságot teremtett az is, hogy figyelembe kellett venni az elkövetőnek az ölési szándék keletkezése és annak megvalósítása közötti időszakban fennálló lelkiállapotát is, ami szintén nehezen tisztázható."

Az 1961. évi V. törvényt jó néhány novelláris módosítás érintette. Ennek során különösen az 1971. évi 28. tvr. hatályba lépését követően - a jogalkotó szükségesnek talált egy korszerü, átfogó szabályozást. A kodifikáció a büntetési rendszerrel kapcsolatosan három szempontot jelölt meg: az indokolatlan szabadságvesztés csökkentését és a szabadságvesztéssel nem járó jogkövetkezmények arányának növelését, a reális büntetési tételek meghatározását, végül a visszaesőkkel szemben hatékonyabb eszközök alkalmazását. ${ }^{17}$

\subsection{Az 1978. évi IV. törvény}

Az 1978. évi IV. törvény az említetteknek megfelelően a korábbiaktól eltérő szankciórendszert kodifikált, továbbá a büntetés célját - részben a tettbüntetőjogi elméletek irányába is mutatva -, valamint a büntetés kiszabásának elveit is újszerüen határozta meg. Föbüntetésnek tekintette a halálbüntetést, a szabadságvesztés-büntetést, a szigorított javító-nevelő munkát, a javító-nevelő munkát, illetőleg a pénzbüntetést. Az új szabályok ismerték a mellékbüntetések mellett az intézkedéseket is.

A büntetés kiszabásának elveit a 83. § rögzítette: „a büntetést - céljának (37. §) szem elött tartásával - a törvényben meghatározott keretek között úgy kell kiszabni, hogy igazodjék a büncselekmény és az elkövető társadalomra veszélyességéhez, a bünösség fokához, továbbá az egyéb súlyositó és enyhítö körülményekhez."A Büntető Törvénykönyv miniszteri indokolása szerint: „súlyositó és enyhítő minden olyan körülmény, amelyet a büntetés kiszabásánál a büntetés céljának megvalósitása érdekében figyelembe kell venni." ${ }^{18}$ A joggyakorlatot irányító kommentár megjegyzi az alábbiakat: „a büntetéskiszabás elveinek alapján kell a bíróságnak a föbüntetések körében az alternatív büntetések közül az alkalmazandót kiválasztania, a büntetési tétel keretei között a büntetés mértékét meghatároznia. Alkalmazni kell ezeket az elveket halmazati büntetés kiszabásánál a büntetés enyhitésénél, a föbüntetés helyett mellékbüntetés kiszabásánál..."19

\footnotetext{
16 Btk. 253. § (1) és (2) bekezdés.

17 GYÖRGYI: i. m., 111.

18 GYÖRGYI: i. m., 289.

19 A Büntető Törvénykönyv Magyarázata - I. kötet, Budapest, Közgazdasági és Jogi Könyvkiadó, 1986, 233.
} 
A Btk. 83. §-ához kapcsolódóan több eseti döntés utalt arra, hogy a büntetéskiszabási körülményeket sohasem elvontan, hanem a konkrét cselekmény és elkövetője vonatkozásában kell vizsgálni. A gyakorlat következetesen alkalmazta a kétszeres értékelés tilalmának elvét. ${ }^{20} \mathrm{~A}$ büntetéskiszabással kapcsolatos szabályok egyébként - és ez jelentős újítás volt a törvényben - részletesen rendezték a tételkeret átlépésének lehetőségeit.

Az új kódex amellett tört lándzsát, hogy a többszörösen minősülö, és így legsúlyosabbnak tekintett, élet elleni cselekmények, továbbá az állam elleni büncselekmények, illetöleg a katonai, valamint a terrorizmussal összefüggő elkövetési magatartások esetén a társadalom védelme nem nélkülözheti a halálbüntetést. ${ }^{21} \mathrm{~A}$ büntetéskiszabás körében a 83. §-ban egyébiránt az 1961. évi V. törvény rendelkezéseihez hasonlóan rögzíti, hogy a halálbüntetést kivételesen, és csak akkor lehet kiszabni, ha a büncselekmény és az elkövető kiemelkedő társadalomra veszélyességére, a bünösség különösen magas fokára figyelemmel a társadalom védelme csak e büntetés alkalmazásával biztosítható. ${ }^{22}$ Ehhez igazodott a bírói gyakorlat is. ${ }^{23} \mathrm{Az}$ 1978. évi IV. törvény hatálybalépésétől 1990-ig a Btk. személy elleni bủncselekmények körében a 166. §-ban szabályozott emberölés alap- és minősített eseteinek büntetési tétele nem változott. Az alapesetben [166. $§(1)$ bekezdés] 5 évtől 15 évig terjedő szabadságvesztéssel fenyegetett büncselekményt rögzít a jogalkotó, míg a 166. § (2) bekezdésében írt minősített esetek megvalósulásakor 10 évtől 15 évig terjedő vagy életfogytig tartó szabadságvesztés alkalmazását, illetőleg halálbüntetés kilátásba helyezését rögzíti a tényállás.

\subsection{A halálbüntetés eltörlésétöl napjainkig}

A halálbüntetés kiiktatásával a büntetési rendszert lefejezték. ${ }^{24}$ Kétségtelen, hogy a határozat kihirdetését követően a legsúlyosabb büntetéssé az életfogytig tartó szabadságvesztés-büntetés vált. Kérdés azonban, hogy ez a büntetés képes-e helyettesíteni a kiiktatott halálbüntetést, illetőleg egyáltalán szükséges-e, hogy helyettesítse azt. ${ }^{25}$

20 BJD 8721, BH 1983/8-308, illetöleg BH 1983/11-434, BJD. 8844.

21 A Büntetö Törvénykönyv Magyarázata - I. kötet, i. m., 112.

22 1978. évi IV. törvény 84. §.

23 A büntetés kiszabását illetően e büntetés alkalmazása valóban kivételes jellegű volt a kor statisztikai adatait is figyelembe véve. A tendencia egyébiránt egyértelmű volt: 1945 és 1990 között fokozatosan csökkent a halálbüntetéssel is fenyegetett deliktumok száma. Magyarországon a halálbüntetés eltörlése előtti 5 éves időszakban a halálbüntetéssel is fenyegetett bủncselekmények miatt összesen 58 életfogytig tartó szabadságvesztést és 12 halálos ítéletet szabtak ki. Vö. Büntetőjog Általános Rész, i. m., 258.

24 Vö. uo, valamint 23/1990. (X. 31.) AB-határozat, vö. ABH 1990, 88-114.

25 A halálbüntetés kiiktatása szakmai vitát gerjesztett arról, hogy hogyan lehet beiktatni egy olyan büntetési nemet, amelynek Magyarországon nincsenek számottevő hagyományai. Megjegyzendő, hogy az alkotmánybírósági határozat meghozatalának időpontjában az életfogytig tartó szabadságvesztés-büntetés nem volt túlságosan fajsúlyos és meghatározó szabadságvesztés-büntetési fajta. (Korábban utaltam arra, hogy az 1961. évi V. törvény kiiktatta az életfogytig tartó szabadságvesztést, mondván, hogy az elítélt átnevelése érdekében nincs szükség életfogytig tartó szabadságvesztés-büntetésre: amennyiben a halálbüntetés kiszabása nem indokolt, a határozott ideig tartó szabadságvesztés alkalmazása megfelel a büntetési céloknak.) 
Az életfogytig tartó szabadságvesztés az 1971. évi 28. tvr.-tel került vissza ismét a szankciórendszerbe, akként, hogy 1971 és 1993 között a feltételes szabadságra bocsátás legkorábbi időpontja 20 esztendő volt, amelyet nem az ügy érdemében eljáró bíró, hanem a büntetés-végrehajtás szabályai határoztak meg, és a büntetésvégrehajtás szabályai szerint került sor az elítélt feltételes szabadságra bocsátására. Az 1993. évi XVII. törvény a feltételes szabadságra bocsátás időpontját 15 és 25 év között állapította meg, és erről már az ítélkező bíró döntött. E jogszabály a feltételes szabadságra bocsátás lehetőségét egyetlen esetben zárta ki: ha az életfogytig tartó szabadságvesztésre ítéltet ismételten életfogytig tartó szabadságvesztésre ítélték.

A szabályok tovább szigorodtak az 1998. évi LXXXVII. törvény 5. §-ával, ${ }^{26}$ amely az életfogytig tartó szabadságvesztés alkalmazása esetén a feltételes szabadságra bocsátás legkorábbi időpontját elévülő cselekmények esetén 20 és 30 év között, míg el nem évülő cselekmény esetén 30 évben határozta meg, s lehetőséget adott arra, hogy a bíróság kizárja a feltételes szabadságra bocsátás lehetőségét. Jól tetten érhető tehát az életfogytig tartó szabadságvesztés-büntetés szabályainak fokozatos szigorodása a 23/1990. (X. 31.) AB-határozat megjelenését követően.

Látható tehát, hogy a 90-es évek végének jogalkotása az életfogytig tartó szabadságvesztés térnyerését eredményezte. Az 1998. évi LXXXVII. törvény által beiktatott szabályozás jelenleg is hatályban van. Úgy látszik, túlélte a szankciórendszer módosításának, illetőleg a Btk. újrakodifikálásának első hullámát. A 2003-tól napjainkig eltelt időszakban ugyanis több kísérlet látott napvilágot a büntetőtörvény szankciórendszerének, illetőleg az egész jogszabálynak az újrakodifikálására. Ezek a törekvések azokban a szabályokban öltöttek testet, amelyek 2010. január 1-jétől, illetőleg május 1. napjától váltak hatályossá. ${ }^{27}$

A jogalkalmazás eldönteni látszik azt a kérdést, hogy a kivételes büntetésként alkalmazott halálbüntetés helyébe a szankciórendszer legsúlyosabb büntetése lépett-e, vagy pedig a halálbüntetés eltörlése kapcsán - annak helyébe - ismételten csupán kivételesen alkalmazható büntetési nem lépett, a tényleges életfogytig tartó szabadságvesztés, amely az elítéltnek a társadalomtól való teljes körű izolációját biztosítja, s az ilyen személy csupán a köztársasági elnök kegyelméből szabadulhat örökös rabságából. A tényleges életfogytig tartó szabadságvesztésre vonatkozó statisztikai adatok annak kivételes jellegét erősítik: a hatálybalépése óta eltelt több mint egy évtizedben az említett büntetéssel mintegy 10-12 elítéltet sújtottak eddig magyar bíróságok.

Az eddigiekben megvizsgáltuk az emberölés bủncselekménye kapcsán a büntetési tételkeret alakulását. Az elmúlt időszakban, bár az alapeset büntetési tételkerete nem változott, a Btk. 166. § (2) bekezdésében felsorolt minősített esetek vonatkozásában lényegesen szigorodott a jogszabály. A 2009. évi LXXX. törvény a büntetési tételkeretet a korábbi 10-től 15 évig terjedő szabadságvesztés helyett 10-től 20 évig terjedő szabadságvesztésre módosította, elfogadva azon jogalkalmazói észrevételeket, amelyek szerint túlságosan nagy volt a távolság az életfogytig tartó szabadságvesztés esetén a feltételes szabadságra bocsátás legkorábbi időpontja meghatározásának lehetősége, és a határozott ideig tartó szabadságvesztés 166. § (2)

\footnotetext{
26 Btk. 47/A. §.

27 2009. évi LXXX. törvény.
} 
bekezdésben elöírt felső határa között. Tudvalévő, hogy a halmazati szabályokat egyetlen cselekmény megvalósítása során még akkor sem lehetett alkalmazni, ha az ölési cselekmény többszörösen minősült. A minősítési rendszerbe új elemként került - szintén a szigorítás jegyében - a védekezésre képtelen személy sérelmére történő elkövetés kodifikálása a 2009. évi LXXX. törvény 43. §-ában.

Az elöbbiekből következően úgy tünik, hogy a halálbüntetés kiiktatásával keletkezett hiányt a jogalkotás és a jogalkalmazás végül is megszüntette. A gyakorlat következetes büntetéskiszabást alakított ki. Az emberölés büntette miatt folyó büntetőeljárásokban a bírósági és a hozzá kapcsolódó ügyészségi hatásköri változások nem eredményeztek a büntetés kiszabása terén szembeötlő eltéréseket a Legfelsőbb Bíróság addigi gyakorlatához képest. ${ }^{28}$

A hatályos Büntetö Törvénykönyv 83. § (1) bekezdése szerint a büntetést a törvényben meghatározott keretek között úgy kell kiszabni, hogy az igazodjék a büncselekmény és az elkövető társadalomra veszélyességéhez, a bünösség fokához, továbbá az egyéb enyhítő és súlyosító körülményekhez. A törvény idézett rendelkezése a bíróságok számára azt a kötelezettséget jelenti, hogy a büntetéskiszabás során figyelembe jövő valamennyi alanyi és tárgyi tényt felderítsék, és a jogkövetkezmények alkalmazásakor értékeljék, ${ }^{29}$ ekként téve eleget az Alkotmány 57 . § (1) bekezdésében rögzített törvény elötti egyenlőség elvének.

Az 56/2007. BK vélemény a büntetést befolyásoló alanyi és tárgyi körülményeket elemzi. Bár a kollégiumi vélemény álláspontja szerint a bírói gyakorlat egysége érdekében szükséges olyan általános iránymutatás, amely felsorakoztatja mindazt, aminek bíróság általi felderítését és értékelését indokoltnak tartja, megállapítja azonban, hogy ugyanazon tény más cselekmény vagy más elkövető vonatkozásában közömbös vagy ellenkező hatású is lehet. A kollégiumi vélemény tehát korántsem teljes, legfeljebb példálózó értékelést ad, egyúttal igen kreatív gondolkodást követel az egyes ügyekben eljáró bírói tanácsoktól.

A Legfelsőbb Bíróság 15. számú irányelve mintha más elveket alkalmazna, mint a kollégiumi vélemény: ,jogpolitikai elveink értelmében a törvény szigorát kell alkalmazni az élet elleni, vagy veszélyeztetö különösen súlyos büncselekmények elkövetőivel szemben. Ilyennek kell tekinteni az útonálló jellegü, garázda indítékból fakadó és a társadalmi közfelháborodást kiváltó élet elleni szándékos büncselekményeket is... a büntetési tétel alsó határán aluli föbüntetés kiszabása kivételes lehetőség... az enyhitő rendelkezések alkalmazása kivételes."

Általában az enyhítő körülmények súlyának, nyomatékának értékelése során azoknak csekélyebb jelentőséget szán az irányelv, folytatva a 14/1973. NET határozatban, valamint a 4. számú irányelvben megjelent elképzeléseket az alanyi és a tárgyi körülmények speciális, a tényálláshoz szorosan kapcsolódó elemzését adva.

28 Vizsgálati jelentés, Debreceni Fellebbviteli Főügyész Bf.275/2006. szám, 2006. július 6. napján, 10.

29 56/2007. BK vélemény. 


\section{2. Értékelés a bírói gyakorlatban}

Az emberöléshez kapcsolódó jogalkalmazás jól láthatóan évtizedek óta nem elégedett meg a büntetés kiszabása során általánosan irányadó bünösségi körülmények felderítésével: csak az emberölés kapcsán irányadó körülmények felderítését, leírását tartja szükségesnek.

Ez több kérdést vet fel:

Érvényesül-e az Alkotmány 57. § (1) bekezdése, vagyis valamennyi büntetőtörvénybe ütköző tényállással kapcsolatos szankcióalkalmazás azonos elvek szerint történik-e?

Igaz-e az az állítás, hogy az emberöléssel kapcsolatos elbírálás évtizedek óta a büntetési tétel középmértékéből indul ki?

Az 1990-től napjainkig tartó jogalkotói tevékenység, illetöleg a bírói gyakorlat alapján kijelenthetö-e az, hogy a feltételes szabadság kizárásával kiszabott életfogytig tartó szabadságvesztés kivételes, és a gyakorlatban önálló büntetési nemként funkcionál?

A továbbiakban publikált jogesetek alapján, az ügyészség már hivatkozott vizsgálati jelentésére hivatkozva, illetve a Debreceni Ítélőtábla előtt befejeződött jogesetekre is figyelemmel szeretnék áttekintést adni az emberölés alap- és minősített eseteivel kapcsolatos ítélkezési gyakorlatról.

Az előbb felvázolt kérdések megválaszolásával kapcsolatosan a Debreceni Ítélötábla emberöléssel kapcsolatos büntetéskiszabási gyakorlatát illetően ügyvizsgálatot végeztünk. ${ }^{30}$

\subsection{Az emberölés alapesetei büntetéskiszabási gyakorlata 2005. január 1.}

és 2010. április 16. között

Az ügyvizsgálat a 2005. január 1. napjától 2010. április 16. napjáig érkezett büntetöügyekre terjedt ki. Az ügyvizsgálat során figyelmen kívül hagytuk azokat az ügyeket, amelyek során a halmazati szabályokat kellett alkalmazni. Figyelmen kívül maradtak az emberölés kísérletével kapcsolatosan keletkezett ügyek, illetöleg nem vettük figyelembe azon ügyeket sem, amelyekben a Btk. szabályai a korlátlan enyhítés lehetőségét engedték meg. Tehát a befejezett emberölés alapeseteit ${ }^{31}$ vizsgálva 46 büntetöügyben 52 vádlottal szemben kiszabott büntetéseket elemeztük.

A statisztikai adatok a következő táblázatban összefoglalt eredményt mutatják.

30 A Btk. 166. § (2) bekezdésével kapcsolatos ügyvizsgálat elvégzéséért köszönet illeti dr. Holhós-Kovács Szilárd bírósági titkárt.

31 Btk. 166. § (1) bekezdés. 
Az emberölés alapesete vizsgálata a 2005. január 1. és 2010. április 16. között érkezett s jogeröre emelkedett ítélettel lezárt ügyekben

\begin{tabular}{|c|c|c|}
\hline $\begin{array}{c}\text { Az ügyvizsgálattal érintett } \\
\text { elítéltek száma }\end{array}$ & $\begin{array}{c}\text { A jogerősen kiszabott } \\
\text { szabadságvesztés mértéke } \\
\text { (év) }\end{array}$ & $\begin{array}{c}\text { Az alkalmazott szabadságvesztés- } \\
\text { büntetések aránya a teljes mintához } \\
\text { viszonyítva }\end{array}$ \\
\hline 1 & 13 & \multirow{3}{*}{$5 \%$} \\
\hline 1 & 12 & \\
\hline 1 & 11 & \\
\hline 38 & 10 & $74 \%$ \\
\hline 3 & 9 & \multirow[b]{2}{*}{$21 \%$} \\
\hline 8 & 8 & \\
\hline Összesen: 52 & 63 & $100 \%$ \\
\hline
\end{tabular}

Megállapítható, hogy az alkalmazott szabadságvesztés büntetések a 10 évi szabadságvesztés büntetés közelében kerültek meghatározásra. Attól 1-2 évvel alacsonyabb mértékben az ügyek körülbelül 1/5-ében, míg afelett csak elvétve, mindösszesen 3 esetben került sor szabadságvesztés büntetés kiszabására. Levonható tehát az a következtetés is, hogy bár a vizsgált időszakban az ún. középmértékes szabály nem volt hatályban, az emberölés alapesete kapcsán a bírói gyakorlat a büntetéseket a büntetési tételkeret középmértékéböl kiindulva határozta meg, a befejezett emberölés büntettének alapesete miatt kiszabott, jogerőre emelkedett ítéletekben.

2. 2. Az emberölés minősített eseteivel kapcsolatos büntetéskiszabási gyakorlat vizsgálata a 2005. január 1. napjától 2010. április 16. napjáig érkezett büntetöügyek vonatkozásában

A vizsgált időszakban a régióból 80 minősített emberöléssel kapcsolatos ügy érkezett a táblabírósághoz, amelyekben 107 terhelt volt érintett. Az ügyérkezés, illetőleg a terheltek száma a tárgyév szerinti megoszlását tekintve sajnálatos módon fokozatosan növekvő tendenciát mutat.

Ezzel ellentétben a kísérleti szakban megrekedt esetek száma csökken. (Ezek mindegyike befejezett kísérlet volt. Kizárólag a szakszerü orvosi ellátás mentette meg a sértettek életét, ahol döntően a sértetti hozzátartozók, barátok kértek orvosi segítséget, így csak a véletlenen múlott, hogy e sértettek halála nem következett be.)

Jelenleg az esetek több mint $2 / 3$-a halálos kimenetelü, és az elkövetöket az sem tartja vissza, hogy a régió büntetéskiszabási gyakorlata enyhének semmiképpen nem nevezhető, egyben állítható, hogy az országos gyakorlatnak is megfelel. 
Az emberölés büntettének minősített eseteivel kapcsolatos ügyérkezés a Debreceni Ítélőtáblán 2005. január 1. és 2010. április 16. napja között, a kísérleti szakban maradt bủncselekmények megjelölésével

\begin{tabular}{|c|c|c|c|c|c|c|}
\hline & 2005 & 2006 & 2007 & 2008 & 2009 & 2010 első negyedév \\
\hline Összesen: & 12 & 11 & 16 & 12 & 24 & 5 \\
\hline Mindösszesen: & \multicolumn{6}{|c|}{80} \\
\hline $\begin{array}{c}\text { \%-os változás } \\
\text { a 2005-ös bázisévhez } \\
\text { képest / előző évhez } \\
\text { képest }\end{array}$ & - & $91,6 \%$ & $\begin{array}{l}133,3 \% / \\
145,45 \%\end{array}$ & $\begin{array}{c}100 \% / \\
75 \%\end{array}$ & $\begin{array}{l}200 \% / \\
200 \%\end{array}$ & $\begin{array}{l}\text { a vizsgált időszak } \\
\text { rövidebb, mint egy } \\
\text { naptári év, ezért } \\
\text { nincs össze- } \\
\text { hasonlítási alap }\end{array}$ \\
\hline $\begin{array}{c}\text { a kísérleti szakban } \\
\text { megrekedt } \\
\text { büncselekmények }\end{array}$ & 4 & 4 & 1 & 1 & 5 & 2 \\
\hline $\begin{array}{c}\text { a kísérleti szakban } \\
\text { megrekedt } \\
\text { büncselekmények } \\
\% \text {-os megoszlása } \\
\text { az ügyérkezéshez } \\
\text { viszonyítottan }\end{array}$ & $33 \%$ & $36,3 \%$ & $6,2 \%$ & $8,3 \%$ & $25 \%$ & $\begin{array}{c}\text { nincs } \\
\text { összehasonlítási alap }\end{array}$ \\
\hline
\end{tabular}

\subsubsection{Az egyszeresen minősülő emberölés bủntette}

Az iratvizsgálatból kitünik, hogy az egyféleképpen minősülő emberölés büntette kapcsán általánosnak a határozott ideig tartó szabadságvesztés alkalmazása mondható. Határozatlan ideig tartó fegyházbüntetés kiszabására e körben mindössze két esetben került sor.

Az egyik esetben az elkövető többedmagával, az országot tipp alapján bejárva, idős személyek otthonába éjjel, így a védekezésre esélyt sem hagyva, anyagi haszonszerzés végett hatolt be, és több millió forintot zsákmányolt. Az idős sértetteket társaival megkötözte, bántalmazta őket, több esetben súlyos sérüléseket is okozott nekik. A nyereségvágyból elkövetett emberölés bủntette miatt több mint 20 rendbeli rablás büntette, személyi szabadság megsértésének bűntette, továbbá néhány rendbeli magánlaksértés bủntette és súlyos testi sértés büntette miatt került felelősségre vonásra. Az eljárás során beismerő, társaira is terhelő vallomást tett, amely nagyban segítette a bíróság munkáját. Határozatlan idejü fegyházbüntetéséből legkorábban 35 év elteltével szabadulhat.

A másik esetben az elkövető különös visszaeső volt. A korábbi büntetése, amelyet testvére életének kioltása miatt kapott, nem bírt kellő visszatartó erővel. Az újabb élet elleni cselekményét ugyan nem hozzátartozó sérelmére, azonban olyan személlyel szemben követte el, aki segítette őt a mindennapi megélhetésben.

Az egyszeresen minősülő emberölés bűntettének vonatkozásában alkalmazott határozott ideig tartó szabadságvesztés tartama büntetett előéletü terheltek esetében döntően az irányadó büntetési tételkeret középmértékéhez közelít, azt eléri. Amenynyiben az elkövető előélete visszaeséssel, vagy többszörös visszaeséssel, netán 
vagyoni bủncselekmények elkövetése miatti különös visszaeséssel volt terhelt, úgy döntően a büntetési tételkeret felső határához közeli fegyházbüntetés került alkalmazásra. Büntetlen előéletü terheltek esetében nagyobb számban a büntetési tétel alsó határához közeli mértékben alkalmaztak az eljárt bíróságok fegyházbüntetést.

Kisebb számban ugyanakkor előfordult büntetett előéletű terheltek esetében a büntetési tétel alsó határához közeli, míg büntetlen előéletű terheltek esetében a felső határhoz közeli tartamú fegyházbüntetés alkalmazása is. Előbbi esetekben a beismerés, megbánó magatartás tanúsítása, kísérleti szakban maradás, illetőleg a közeli hozzátartozó sérelmére történő elkövetés voltak kiemelkedő nyomatékkal figyelembe vett ismérvek.

Az egyszeres minősülés körében külön kiemelést érdemelnek azok az esetek, melyekben a terhelt szülő nő volt, aki újszülöttjével szembeni elkövetői magatartását szülést követően nyomban, vagy kis idő elteltével fejtette ki. Az ilyen cselekmények elkövetői döntően fiatal felnőtt, olykor fiatalkorú személyek voltak. Kivétel nélkül minden esetben sor került az enyhítő szakasz alkalmazására, döntően a végrehajtási fokozat eggyel enyhébb meghatározására is. ${ }^{32} \mathrm{Az}$ enyhítő szakasz alkalmazását az elkövetők fiatal kora, beismerése, megbánása, egy esetben a kísérleti stádiumban maradás [Btk. 87. $\S(2)$ bek. a) pont], vagy a terhelt beszámítási képességének korlátozottsága indokolta [Btk. 24. § (2) bek., 87. § (4) bek.].

A kísérleti szakban maradt esetben az enyhítő körülmények túlsúlya miatt az egyébként példaértékü gyermeknevelést tanúsító terhelt esetében kiszabott két év börtönbüntetést a bíróság öt év próbaidőre felfüggesztette.

A táblabíróságon előfordult kilenc esetben két év és hat év közötti szabadságvesztés kiszabására került sor, s ezek közül csak két esetben nem alkalmaztak az eljárt bíróságok enyhébb végrehajtási fokozatot.

32 A szüléssel járó különleges állapot rendkívül súlyozott enyhítő körülményként kerülhet értékelésre. A 15. számú irányelv útmutatása alapján a büntetéskiszabás körében figyelembe kell venni azt, hogy milyen ok vezette a szülő nőt újszülöttje megölésére, e körben a tudatilag elmaradott környezet nyomasztó súlya és a társadalmi rosszallás nyomatékos enyhítő körülményként értékelendő, azonban az irányelvben felsoroltakon kívül nincs társadalmi, erkölcsi és jogi alapja annak, hogy a törvényi büntetési tétel legkisebb mértékén aluli büntetés általánossá váljék. Az irányelv megfogalmazása szerint a BH.1988.259. számú döntés iránymutatása továbbra is irányadó, mely szerint az újszülött közvetlen szülés után történő megölése esetében a közeli hozzátartozói viszony súlyosító körülményként nem értékelhető, mint ahogyan a terhesség eltitkolása sem. Megjegyzendő e körben azonban az is, hogy a 2003. március 1. napját megelőző ítélkezési gyakorlat is a szülő nő szüléskori állapotából indult ki. (BH 1983/178, BH 1999/433, BH 2000/186, BH 2000/527, BH 2001/354, BH 2002/44, BH 2002/128, EBH 2001/390) A minősített emberölésekhez képest ezt az enyhébb ítélkezési gyakorlatot az 1998. évi LXXXVII. törvény 40. §-a is elismerte, és az újszülött megölését az emberölés privilegizált eseteként szabályozta (Btk. 166/A. §), 2-8 éves büntetési tételkeretet felállítva arra. E szabályozást a 2003. évi II. törvény 88. § (1) bek. e) pontja 2003. március 1. napjától helyezte hatályon kívül, holott ugyancsak az 1998. évi LXXXVII. törvény rendelte minősített emberölésként büntetni a 14 . életévét be nem töltött személy elleni emberölést, 10 évtől 15 évig terjedő, vagy életfogytig tartó szabadságvesztés kiszabását is lehetővé téve azon esetekre. Ugyanakkor a 2003. évi II. törvény a Btk. 33. § (2) bekezdés c) pontjába nem iktatta be a 14. életévét be nem töltött személy ellen elkövetett emberölést olyan cselekményként, mely elévül. Ebből következően a jogszabályi környezet nem kezeli e minősített esetet a többivel azonos tárgyi súlyú bűncselekményként. Vö. Bf.I.127/2008, Bf.I.555/2007. sz. ügyek. 
Az emberölés bủntettének minősített eseteivel kapcsolatos ügyek száma a Debreceni Ítélőtáblán 2005. január 1. és 2010. április 16. napja között*

\begin{tabular}{|c|c|c|c|c|c|c|}
\hline 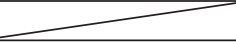 & \multicolumn{6}{|c|}{ A vizsgált évben az adott minősítéssel érintett ügyek száma } \\
\hline $\begin{array}{l}\text { Btk.166. } \S(1),(2) \\
\text { bekezdés }\end{array}$ & 2005 & 2006 & 2007 & 2008 & 2009 & $\begin{array}{l}2010 \text { első } \\
\text { negyedév }\end{array}$ \\
\hline a) pont & 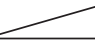 & 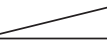 & 2 & 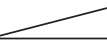 & 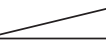 & 2 \\
\hline b) pont & 2 & 2 & 2 & 1 & 3 & 2 \\
\hline c) pont & 1 & 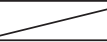 & 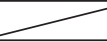 & 2 & 1 & 2 \\
\hline d) pont & 5 & 2 & 5 & 3 & 10 & 1 \\
\hline e) pont & 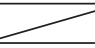 & 1 & $\infty$ & $\infty$ & $\infty$ & 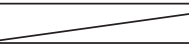 \\
\hline f) pont & 1 & 1 & 2 & 1 & 1 & 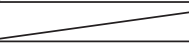 \\
\hline g) pont & 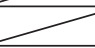 & 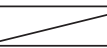 & 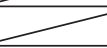 & 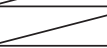 & $>$ & 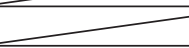 \\
\hline h) pont & 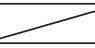 & 1 & 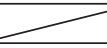 & 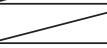 & $\infty$ & 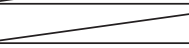 \\
\hline i) pont & 1 & 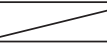 & 2 & 4 & 2 & 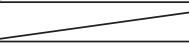 \\
\hline $\begin{array}{l}\text { Kétszeres } \\
\text { minősülés }\end{array}$ & 1 & 5 & 4 & 3 & 7 & 2 \\
\hline $\begin{array}{l}\text { Többszörös } \\
\text { minősülés }\end{array}$ & 2 & 1 & 1 & 1 & 1 & 2 \\
\hline Összesen & 12 & 13 & 16 & 12 & 25 & 5 \\
\hline Mindösszesen & & & & 83 & & \\
\hline
\end{tabular}

* Megjegyzések a táblázatban foglaltakhoz:

1. A Btk. 2. § főszabályára figyelemmel, a 2009. augusztus 9. napjától szabályozott Btk. 166. § (2) bek. j) pont szerinti minősítéssel kapcsolatos ügy a vizsgált időszakban nem fordult meg a táblabíróságon.

2. Az ügyérkezéshez képest az eltérés oka, hogy 3 ügyben egyes terheltek nem minden sértett életének kioltásában vettek részt, így esetükben az emberölés bủntette csak egyféleképpen minősült, társaik esetében azonban az f) pont szerint is, így utóbbi eseteket a kétszeres minősülés körében vettük számba.

Egyéb esetekben elhanyagolható mértékben került sor az enyhítő szakasz alkalmazására, amit döntően a terhelt beszámítási képességét is érintő kóros elmeállapota, vagy fiatal felnőtt kora, elhanyagolható számban a terhelt megromlott egészségi állapota, vagy a kísérlet távolisága indokolt. A már említett esetben például a néhány hetes babájának elhanyagolásával, gondozói kötelességének személyisége éretlen voltából fakadó elmulasztásával valósította meg a fiatal felnőtt terhelt az emberölés minősített esetét, majd cselekményét beismerte, és az eljárás során mélyen megbánó magatartást tanúsított. Emiatt vele szemben is sor került a Btk. 87. § (2) bekezdés a) pontjának és a Btk. 45 . $§(2)$ bekezdés rendelkezésének alkalmazására. ${ }^{33}$

\subsubsection{A kétszeresen vagy többszörösen minősülő emberölés bűntette}

A kétszeresen vagy többszörösen minösülö emberölés büntettével kapcsolatos ügyekben jól érzékelhetően masszív főbüntetések kerültek alkalmazásra. A föbüntetések tartamának meghatározása során az eljárt bíróságok az esetek döntő többsé-

33 Bf.I.48/2008. számú ügy. 
gében a határozott ideig tartó szabadságvesztés büntetési tételkeretének maximumát alkalmazták. A halmazati szabályok alkalmazásával több esetben 20 év fegyházbüntetés is kiszabásra került. A határozott ideig tartó szabadságvesztésnél irányadó büntetési tételkeret felső határát el nem érő büntetések mindegyikénél elmondható, hogy a terhelt fiatal felnőtt kora, beismerése vagy a kísérleti szak volt mérvadó.

Enyhítő szakasz alkalmazására távoli kísérlet, korlátozott beszámítási képesség, illetőleg a fiatal felnőtt kor miatt - beismerés mellett - elhanyagolható mértékben került sor. Egy esetben alkalmatlan kísérlet folytán a Btk. 17. § (2) bekezdésének alkalmazásával szabott ki a bíróság büntetést.

Határozatlan tartamú szabadságvesztést nyolc terheltre - egy esetben tényleges életfogytig tartó fegyházbüntetést - szabtak ki az eljárt bíróságok. Hét elkövetővel szemben bűnözői életformájuk, illetőleg az általuk véghezvitt büncselekmény rendkívül durva, embertelen, a sértettek emberi mivoltát mélyen megalázó, orvtámadásszerü, gátlástalan elkövetése tette indokolttá e büntetési nem alkalmazását. Egy esetben ugyan büntetlen előéletű terhelt felett ítélkezett a bíróság, azonban az általa véghezvitt embertelen elkövetés (két alvó, kiskorú gyermekét hidegvérrel, késsel, több szúrással kivégezte) a személyében rejlő oly mértékủ társadalomra veszélyességröl árulkodott, hogy vele szemben határozott ideig tartó szabadságvesztés alkalmazására szintén nem kerülhetett sor.

Feltételes kedvezményből a bíróság azt a terheltet zárta ki, aki társaival együtt az országot tippek alapján bejárva idős, védekezésre alig képes sértettekre tört rá álmukban, haszonszerzés reményében. Amint erről korábban már szó volt, a terhelt megbánást nem tanúsított és a hatóságokkal sem müködött együtt. A sorozatos büncselekmények során a társak közül a legdurvább fellépést ő tanúsította.

A kiszabott mellékbüntetések tartama szinte kivétel nélkül igazodott a föbüntetés tartamához. Az elöbbiekből - a táblázatokat is áttekintve - egyrészt szintén az állapítható meg, hogy a bíróságok a büntetési tételkeret középmértékéböl kiindulva alkalmazzák a határozott ideig tartó szabadságvesztést, másrészt rögzíthető általában az a tapasztalat, hogy az életfogytig tartó szabadságvesztés kiszabása során a feltételes szabadság kizárása kivételes. 
A Debreceni Ítélőtáblára 2005. január 1. és 2010. április 16. napja között érkezett, emberölés bủntettének minősített eseteivel érintett terheltek száma

\begin{tabular}{|c|c|c|c|c|c|c|}
\hline & \multicolumn{6}{|c|}{$\begin{array}{l}\text { A vizsgált évben az érintett terheltek száma, } \\
\text { külön megjelölve a társas elkövetői alakzatot }\end{array}$} \\
\hline $\begin{array}{l}\text { Btk. } 166 . \S(1) \text {, } \\
\text { (2) bekezdés }\end{array}$ & 2005 & 2006 & 2007 & 2008 & 2009 & $\begin{array}{l}2010 \text { első } \\
\text { negyedév }\end{array}$ \\
\hline a) pont & & & 2 & & & \\
\hline b) pont & 2 & 2 & 3 & $\begin{array}{l}4 \\
2 \text { társt. } \\
1 \text { felb. } \\
1 \text { büns }\end{array}$ & $\begin{array}{c}4 \\
2 \text { társt. } \\
1 \text { büns. }\end{array}$ & \\
\hline c) pont & 1 & & & & 1 & \\
\hline d) pont & 5 & $\begin{array}{c}4 \\
3 \text { társt. }\end{array}$ & 5 & $\begin{array}{c}6 \\
4 \text { társt. }\end{array}$ & 10 & 1 \\
\hline e) pont & & 1 & & & & \\
\hline f) pont & & 1 & & & 1 & 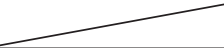 \\
\hline \multicolumn{7}{|l|}{ g) pont } \\
\hline h) pont & & 1 & & & & \\
\hline i) pont & 1 & & 2 & 3 & 2 & \\
\hline $\begin{array}{l}\text { Kétszeres } \\
\text { minősülés }\end{array}$ & 1 & $\begin{array}{c}10 \\
8 \text { társt. }\end{array}$ & $\begin{array}{c}6 \\
2 \\
\text { bünsegéd }\end{array}$ & $\begin{array}{l}5 \\
2 \text { társt. } \\
1 \text { büns. }\end{array}$ & $\begin{array}{l}11 \\
5 \text { társt. } \\
1 \text { büns }\end{array}$ & 2 \\
\hline $\begin{array}{l}\text { Többszörös } \\
\text { minősülés }\end{array}$ & 2 & 1 & 1 & $\begin{array}{c}2 \\
\text { társt. }\end{array}$ & 1 & $\begin{array}{c}3 \\
2 \text { társt. }\end{array}$ \\
\hline Összesen & 12 & $\begin{array}{c}20 \\
11 \text { társt. }\end{array}$ & $\begin{array}{l}19 \\
2 \\
\text { bünsegéd }\end{array}$ & $\begin{array}{l}20 \\
9 \text { társt. } \\
2 \text { büns. } \\
1 \text { felb. }\end{array}$ & $\begin{array}{c}30 \\
7 \text { társt. } \\
2 \text { büns. }\end{array}$ & $\begin{array}{c}6 \\
2 \text { társt. }\end{array}$ \\
\hline Mindösszesen & \multicolumn{6}{|c|}{$\begin{array}{c}107 \\
\text { ebből } 29 \text { terhelt társtettesi minőségben, } \\
6 \text { terhelt bủnsegédként és } 1 \text { terhelt felbujtóként követte el a minősített emberölést }\end{array}$} \\
\hline
\end{tabular}

\subsection{Az ügyvizsgálat további tapasztalatai}

Az ügyvizsgálat során azon túl, hogy fö kérdés a tényleges büntetéskiszabási gyakorlat alakulása volt az emberölés alap- és minősített eseteivel összefüggésben, több esetben találtam eltérő megítélést. Ezeket a pontokat csupán utalásszerủen foglalom össze:

A minősített esetek vonatkozásában eltérő elképzelések jelentek meg az előre kitervelten elkövetett emberölés megállapítása, megállapíthatósága körében. A problémát részben az jelentette, hogy szükséges-e, és ha igen, milyen időintervallum eltelte e minősített eset megállapításához, s a minősített eset megállapításával kapcsolatosan milyen egyéb feltételek fennállása szükséges. 
A Legfelsőbb Bíróság BKv. 56. sz. kollégiumi véleménye alapján az egyes bűnösségi körülmények vonatkozásában az alábbi esetekkel kapcsolatosan volt jogalkalmazói bizonytalanság észlelhető:

Ismételten felvetődött az ellentmondás, hogy jóllehet az eshetöleges szándék enyhítő körülmény, az egyenes szándék nem tekinthető súlyosítónak.

Felmerült továbbá a közeli hozzátartozó sérelmére elkövetett élet elleni büncselekmény vonatkozásában az, hogy az ilyen körülmény ténylegesen súlyosító körülményként értékelendő, azonban ennek felsorolása és a büntetés körében történő értékelése elmaradt.

A használt eszköz különös veszélyességének értékelése néhány határozatban nem volt egyértelmü. Ebben a körben különösen a késhasználattal kapcsolatosan merült fel eltérés az alkalmazott eszköz pengehosszúságát illetően. Előfordult, hogy kis pengehosszúságú kést különösen veszélyes eszköznek tekintettek, míg más ügyben hosszabb pengehosszúságú eszköz vonatkozásában mellőzték a különös veszélyesség értékelését, és ennek megjelenítését a büntetéskiszabás körében.

Nem volt egyértelmű a visszaesés súlyosító körülménykénti kezelése. Az ügyekben a visszaesői minőség általában súlyosítóként szerepelt, azonban nem volt utalás arra az esetre, és nem értékelték a bíróságok külön súlyosítóként azt a helyzetet, amikor a visszaesést megalapozó büntetésen kívül is volt büntetve az elkövető.

Hasonlóképpen problémát vetett fel a bűnhalmazat súlyosítókénti értékelése, illetőleg láthatóan eltérő eredményhez vezetett a büntetőeljárás alatti elkövetés kérdése, továbbá az időmúlás enyhítő körülményként történő kezelése. Ebben a körben több határozatban - álláspontom szerint - helyesen került rögzítésre, hogy az időmúlás enyhítőkénti kezelése függ a büntetőeljárással összefüggésben eltelt idő mértékétöl és attól, hogy ezen idő milyen viszonyban van a különös részi büntetési tételkerettel. Nagyobb arányú időmúlás nyilvánvalóan azt jelenti, hogy a büntetési tételkeret jó részét a terhelt büntetőeljárás alatt töltötte, illetőleg ezekben az ügyekben ez a helyzet fogva tartási körülmények között realizálódik.

Az említetteken túlmenően eltérő álláspontra helyezkedtek a bíróságok a beismerő vallomás, illetőleg a részbeni beismerő vallomás enyhítőkénti értékelésének kérdésében, s hasonlóképpen nem volt egységes a jogalkalmazás a beszámítási képességet nem érintő személyiségzavar értékelése körében sem.

\section{3. Összegzés}

Az ügyvizsgálat tapasztalatai alapján álláspontom szerint a feltett kérdésekre az alábbi válaszok adhatók, illetőleg az alábbiakat tükrözi a bírói gyakorlat:

ad 1. A speciális rendelkezéseket az emberi élet kimagasló társadalmi értéke indokolhatja. A bírói gyakorlat elfogadja és széleskörüen, stabilan alkalmazza a Legfelsőbb Bíróság 15. sz. irányelvének IV. pontjából a büntetéskiszabás vonatkozásában adott útmutatást. Intézményes alkotmányossági aggály a Legfelsőbb Bíróság 15. sz. irányelve vonatkozásában nem fogalmazódott meg, bár mindenképpen indokoltnak tűnik az irányelvet felváltó olyan jogegységi határozat meghozatala, amely a büntetéskiszabási kérdéseken túlmenően átfogja az irányelvben felvázolt valameny- 
nyi kérdést. Ez nyilvánvalóan elképzelhető több jogegységi határozat keretei között is.

ad 2. Az emberölés alapesetével kapcsolatos ügyvizsgálat körében megállapítható, hogy a bíróságok a büntetési tételkeret középmértékéböl indulnak ki. Ez a bírói gyakorlat hosszú ideje töretlen, függetlenül attól, hogy az általános részben van-e erre vonatkozó instrukció vagy nincs. Hasonló megállapítás tehető a minősített esetekhez kapcsolódó, határozott ideig tartó szabadságvesztés alkalmazásáról is. Ebben a körben megfontolandónak és megszívlelendőnek tartom a fellebbviteli föügyészség vizsgálati anyagát. A vizsgálati anyag szerint ugyanis a középmértékes szabály hiányában az emberölés alapesetének megállapításakor az enyhítő és súlyosító körülmények esetében a hatályos büntetőjogi szabályok szerint az emberi élet védelméhez kapcsolódó büntetőjogi szabály alapján ötévi szabadságvesztés kiszabására lenne lehetőség. ${ }^{34}$ Megjegyzendő, hogy e körben a büntetési tételkeret emelésére a minősített esetek vonatkozásában került sor, s 2009 nyarától hatályos az ismételten kodifikált középmértékes szabály is. ${ }^{35} \mathrm{~A}$ bírói gyakorlat tehát hosszú évtizedek óta a középmértékes szabályt alkalmazva dönt az emberölés alapesete és minősített esete vonatkozásában a jogkövetkezmények alkalmazásáról. Ebben a körben megjegyzendő, hogy az emberölés minősített esetei kapcsán, amennyiben a bíróságok határozott ideig tartó szabadságvesztés-büntetést szabtak ki, szintén irányadónak tekintették az ún. középmértékes szabályt, függetlenül attól, hogy e szabály hatályban volt-e vagy sem. A már korábban idézett, fellebbviteli föügyészségi vizsgálati anyag álláspontom szerint helyes megállapítást tartalmaz az emberölés bủncselekményével kapcsolatos szankciórendszer kialakításáról: olyan büntetési rendszer vagy tételkeret kialakítása szükséges, amely valóban hủen tükrözi az egyszeri, megismételhetetlen emberi élet semmi máshoz nem hasonlítható, mással össze nem vethető, kimagasló társadalmi értékét. ${ }^{36}$

ad 3. Az ügyvizsgálat alapján nyert statisztikai adatokból, a mintegy tíz év bírói gyakorlatából, illetőleg a büntetés-végrehajtási adatokból levont következtetés alapján állítom, hogy a feltételes szabadság kizárásával kiszabott életfogytiglani szabadságvesztés-büntetés kivételes büntetési nemként funkcionál. A tétel igazsága esetén - márpedig minden adat ezt igazolja - feltétlenül szükséges lenne az alkalmazás feltételeit konkrétan a törvényben meghatározni, ugyanis mind a Btk. 47. §-ában, ${ }^{37}$ mind pedig az erőszakos többszörös visszaeséssel kapcsolatos szabállyal összefüggésben, ${ }^{38}$ illetöleg az utóbb elhelyezett halmazati büntetés alkalmazásával kapcsolatos szabály esetén ${ }^{39}$ az életfogytig tartó szabadságvesztés alkalmazásának lehe-

34 Vizsgálati jelentés, i. m., 9.

35 Btk. 83. § (2) bekezdése, hatályos a 2010. évi LVI. törvény 1. §-a alapján 2010. augusztus 23-tól.

36 Vizsgálati jelentés, i. m., 9.

37 Btk. 40. § (3) bekezdés, Btk. 47/A. § (1) és (2) bekezdés.

38 Btk. 137. § 17. pont.

39 Btk. 85. § (4) bekezdés. 
tőségét vagy kötelező alkalmazásának törvényi feltételeit jeleníti meg a Büntető Törvénykönyv, s nem foglalkozik az ún. tényleges életfogytig tartó szabadságvesztés alkalmazhatóságának „„öbblet-feltételrendszerével”. E körben csupán néhány bírósági határozat jelent meg, amelyek bár igyekeznek meghatározni e büntetési nem alkalmazásának szempontjait, azonban nem nyújtanak kimerító útmutatást, s nem utolsósorban e szabályok a gyakorlatot orientálják, s nem pótolják a nyilvánvalóan szükséges, törvényi szintủ szabályozást.

\section{Abstract}

The Autor examined the sentencing practice of the Regional Court of Appeal of Debrecen in homicide cases. The conclusion of his paper is, based on the examination of relevant case law, that courts regard the medium of the custody range as a basis for sentencing in homicide cares. This practice is independent of the relevant requirements provided by the General Part of the Criminal Code. The author also states, according to the examination mentioned above, that a life impissonment without the possibility of parote, is only exceptionally in the recent practice. 